\title{
希硫酸溶液中における黒鉛サスペンション法による 銅のエッチング機構
}

\author{
沖 猛雄 ${ }^{*}$. 国枝 義彦**

\begin{abstract}
Etching Mechanism of Copper by Graphite Suspension
in Dilute Sulfuric Acid Solution
\end{abstract}

Takeo OKI* and Yoshihiko KUNIEDA**

\begin{abstract}
The effect of surface area of graphite particles on the etching rate of copper was mainly investigated and based upon the experimental results the etching mechanism of copper is briefly discussed. The potential of the graphite suspension corresponds to the redox potential of a system consisting of graphite and its oxidized species formed at the anode. The suspension-potential is mainly controlled by the quantity of electricity accumulated per unit surface area of graphite particles by anodizing. The etching velocity of copper in the suspension increases with the increase in the total surface area of graphite particles striking the copper plate per unit time. The etching rate divided by the apparent surface area of graphite in the unit volume of the suspension increases with increasing concentration of graphite, but decreases with decreasing diameter of graphite particles. The etching of copper takes place according to the local cell reaction consisting of $\mathrm{Cu} \rightarrow \mathrm{Cu}^{2+}+2 \mathrm{e}$ as anodic reaction and $(\mathrm{C}-\mathrm{OH})+$ $\mathrm{H}^{+}+\mathrm{e} \rightarrow \mathrm{C}+\mathrm{H}_{2} \mathrm{O}$ and partly $\mathrm{O}_{2}+4 \mathrm{H}^{+}+4 \mathrm{e} \rightarrow 2 \mathrm{H}_{2} \mathrm{O}$ as cathodic reactions.
\end{abstract}

\section{1. はじめに}

銅の新しいエッチング法として黒鉛サスペンションに よる電気化学的なエッチング法一隔膜により陰極と分離 した陽極室で黒鉛粒子をサスペンション電解し，試料銅 板から電気化学的に銅を溶出させ，陰極に同時に金属銅 を回収する方法一は，従来の化学的エッチング法に比べ 液の老化，アンダーカット，金属回収など種々の問題を 解決しらる注目すべき有効な方法である11。前報2に拧 いては，黒鉛サスペンションのアノード電解に拈いて黒 鉛粒子が電解酸化されて高電位を保有するようになるこ と，また黒鉛酸化の陽極電流密度は主として単位時間に 衝突する黒鉛粒子の総表面積に依存すること，および銅 のエッチング速度は同一黒鉛粒度では懸濁量が多い程, また同一㲘濁量では粒度が小さい程大きく，さらに溶液 の温度が高いほどまた $\mathrm{pH}$ が低い程大きいことを明らか にした。ところで, Faul ら¹) は銅のエッチング機構につ いては黒鉛粒子の衝突頻度および 2 重層容量から若干説 明しているが，これらでは前報の実験結果を十分に説明

*名古屋大学工学部 (广464 名古屋市千種区不老町) Fac. of Eng., Nagoya Univ. (Furo-cho, Chikusaku, Nagoya 464)

**同上, 現在の勤務先は鈴鹿工業高等専門学校 （干510-02 三重県鈴鹿市白子町）

Suzuka College of Tech. (Shiroko-cho, Suzuka, Mie 510-02)
できない。そこで本報告では, サスペンション電位およ び銅エッチング速度の懸濁黒鉛表面積に対する依存性お よび黒鉛の懸濁量や粒度の効果を考察し, 黒鉛サスペン ション法による銅エッチング機構について検討する。

\section{2. 実験方法}

実験装置は図 1 のようで，実験は前報と同様な方法で 行なった。溶液は $0.5 \mathrm{M}$ 硫酸溶液を用いた。参照電極は 飽和カロメル電極 (SCE) を使用し, サスペンションの 電位は Pt 電極を用いて測定した。Ptネット陽極の電位 は常に $1 \mathrm{~V}$ に保持した。

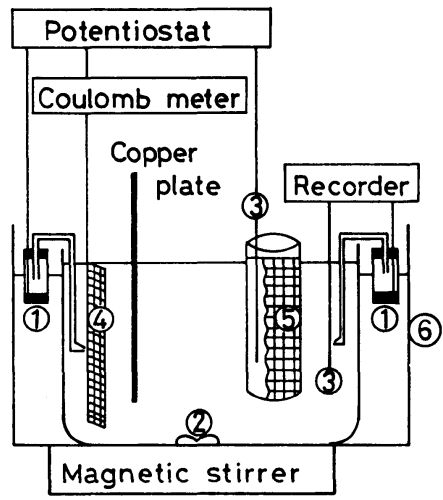

(1) SCE

(2) Agitator

(3) Pt electrode

(4) Pt net el ectrode

(5) Filter cloth

(6) Thermostat

Fig. 1 Schematic representation of the cell construction for the etching of copper. 


\section{3. 実験結果および考察}

\section{3-1 サスペンション完位と必要電気田の黑鉛表面積} に対する依存性

$0.5 \mathrm{M}$ 硫酸溶液中で黒鉛の粒度あるいは懸濁量を変化 させ，電解した時のサスペンションの電位と流れた電気 量 $C$ (coulomb) との関係は前報で示したように図 2(a) となった。サスペンション電位は電気量の増大とともに 上昇し，アノード設定電位 (1V) に近い值となる。サ スペンション電位の上昇のためには 150 メッシュ以上を 除いて, 同一懸濁量で粒度の細かい程, また同一粒度で も眊濁量の多い程, 多くの電気量を必要とする。このサ スペンション電位と流れた電気量の黒鉛表面積に対する 依存性を検討するため, 次のように考察した。サスペン ション電解により黒鉛単位表面積当り酸化物生成のため に消費される電気量 $C_{a}\left(\right.$ coulomb $\left.\mathrm{m}^{-2}\right)$ は次式で与え られる。

$$
\begin{array}{r}
C_{a}\left(\text { coulomb } \cdot \mathrm{m}^{-2}\right)=C(\text { coulomb }) / \\
S_{v}\left(\mathrm{~m}^{-1}\right) \cdot V\left(\mathrm{~m}^{3}\right)
\end{array}
$$

ここに, $S_{v}$ と $V$ はそれぞれ単位容積中の懸濁黒鉛の 総面積拉よび溶液の体積を示す。いま, $V$ は $1 l$ と一定で ある。そこでサスペンション電位と $C / S_{v}$ との関係を図

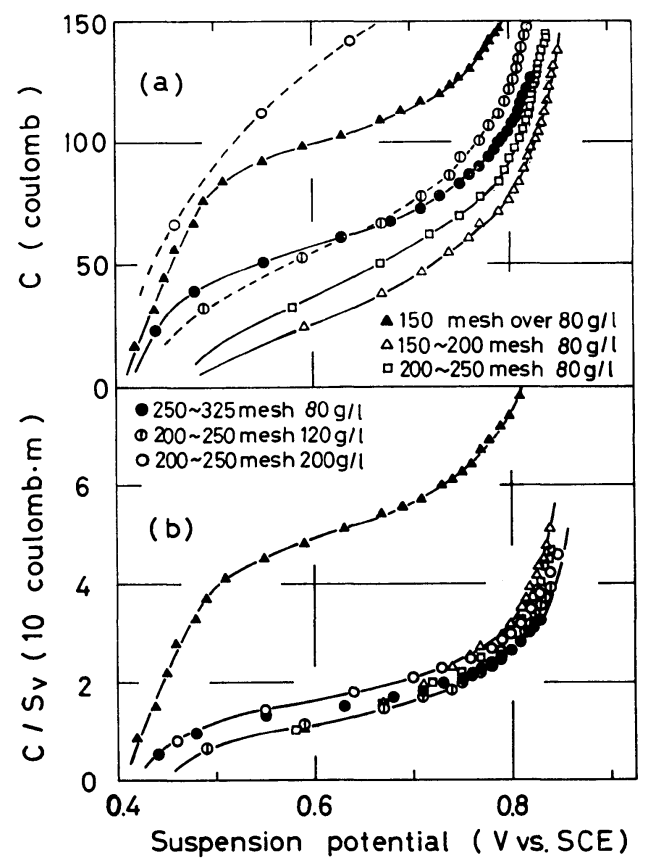

Fig. 2 (a) Relations between the suspension potential and the quantity of electricity $C$ accumulated on graphite particles by anodizing.

(b) Relations between the suspension potential and $C / S_{v} . \quad S_{v}$ is the total surface area of graphite particles in unit volume of the suspension.
2 (b)に示す。ここに各粒度にお忊る粒径は 150 メッシュ 以上 $\left(1.05 \times 10^{-4} \mathrm{~m}\right), 150 \sim 200 \times ッ シ ュ\left(8.95 \times 10^{-4} \mathrm{~m}\right)$, $200 \sim 250 \times ッ シ ュ\left(6.85 \times 10^{-4} \mathrm{~m}\right), \quad 250 \sim 325 \times ッ シ ュ$ $\left(5.35 \times 10^{-5} \mathrm{~m}\right)$ と各々の平均值をとり, この粒径から 見掛け上の球の表面積として $S_{v}$ を算出した。サスペン ション電位と $C / S_{v}$ との関係は 150 メッシュ以上の粒径 の例外を除いて,ほぼ同一曲線で示される。すなわち, サ スペンション電位は黒鉛単位表面積当り, 酸化物生成に 消費される電気量によって決まり，この電気量が多くな ると貴となることが明らかになった。このことから同一 温度で黒鉛表面にチャージされている電気量 $C_{a}$ をサス ペンション電位 $E_{\text {sus }}$ の測定から知ることができ，この 電位 $E_{s u s}$ での黒鉛粒子に保持される電気量を $C_{s u s}$ と すると, $C_{a}$ が温度 $T$ との関数でもあるので次式の関係 が与えられる。

$$
C_{a}=f\left(E_{s u s}, T\right)=C_{s u s}
$$

また, 150メッシュ以上の場合に挙動が異なることは, 粒径が大きくて陽極で酸化されにくく, 電気量の損失に 起因すると考えられる。また图 2 (b) で帯状になったの は, 後の 3-2で考察するように, 表面粗さなど黒鉛粒子 の表面性質による実際の表面積の違いばかりでなく懸濁 量が増大したさい，陽極に衝突する黒鉛粒子間が互いに 結着してつながることに原因があると考兄られる。図 2 (b)の曲線は真の表面積を用いるならば, 同一曲線で示す ことができると思われる。

次に，黒鉛懸濁状態におけるサスペンション電位と電 解質溶液のレドックス系の電位との違いを明らかにする ために，サスペンション電位が0.95Vを示している状態 で電解とかくはんを停止した。この時の溶液の電位変化 を図 3 に示す。懸濁黒鉛は沈降し，サスペンション電位 は時間の経過とともに放物線的に下降した。約 3.5 時間 後, 溶液の電位は0.59Vを示した。これを再かくはんす るとサスペンション電位はすぐ淁 $0.92 \mathrm{~V}$ に達し安定であ

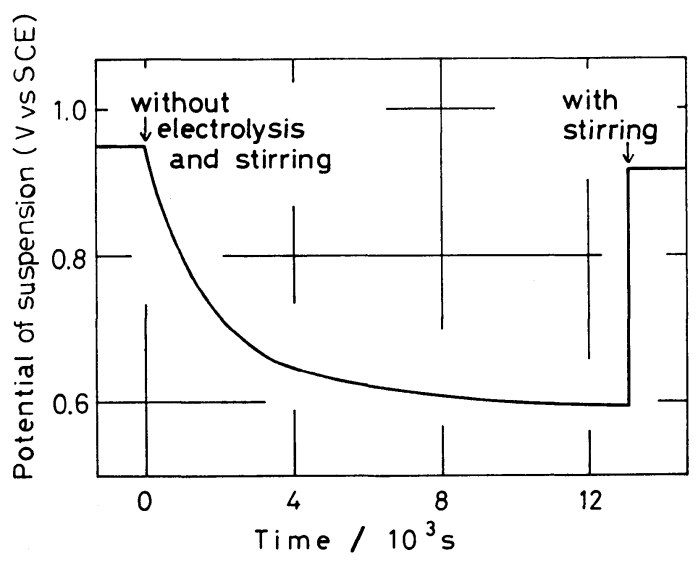

Fig. 3 Changes in the potential of suspension with time. 
った。これらのことより黒鉛が懸濁していない時の溶液 の電位は電解質溶液中の溶存酸素のレドックス系,

$\mathrm{O}_{2}+4 \mathrm{H}^{+}+4 \mathrm{e}=2 \mathrm{H}_{2} \mathrm{O}$

$E=1.23-0.0118 \mathrm{pH}+0.0295 \log \mathrm{AO}_{2}$

の電位を示す。

また，サスペンション電解で黒鉛粒子は陽極で電解酸 化され，ハイドロキノンのようなグループ $(\mathrm{C}-\mathrm{OH})$ ， あ るいはキノンのよらなグループ（C-O) の酸化物を生成 することが知られている ${ }^{2,3)} 。$

$(\mathrm{C}-\mathrm{OH})+\mathrm{H}^{+}+\mathrm{e}=\mathrm{C}+\mathrm{H}_{2} \mathrm{O}$

$\left((\mathrm{C}-\mathrm{O})+\mathrm{H}^{+}+\mathrm{e}=(\mathrm{C}-\mathrm{OH})\right.$

あるいは, $(\mathrm{C}-\mathrm{O})+2 \mathrm{H}^{+}+2 \mathrm{e}=\mathrm{C}+\mathrm{H}_{2} \mathrm{O}$

したがって，再かくはん後の電位が電解前の電位に近 い0.92Vと貴な電位を示したことは，これらの黒鉛酸化 生成物が水溶液中で安定であることを示し，この黒鉛の サスペンション電位は上述の黒鉛-酸素種 $(-\mathrm{OH},-\mathrm{O})$ 系 のレドックス電位である。

\section{3-2 銅エッチングへの黒鉛表面積の効果}

黒鉛のサスペンションをアノード電解するとサスペン ション電位は, 図 2 に示されたように電気量の増加に伴 ない上昇し，注ぼ設定電位に近い電位（最大サスペンシ ョン電位と記す）に到達する。この時のアノード電流は 初期に顥著に上昇し, その後徐々に減少し, 最大サスぺ ンション電位に達する頃には微小な電流 (残余電流 $I_{r}$ ) が流れる状態となる。この状態に銅板を浸すとアノード 電流は増大して，しばらくして安定な電流 $I_{s}$ となる， 銅板を浸した時のサスペンション電位は最大電位より急 激に下降して一定電位で葟ぼ安定する。銅板を取り去る とサスペンション電位は上昇して最大サスペンション電 位に，またアノード電流は残余電流に達する。そこでこ れらの陽極電流密度および銅エッチング速度への懸濁黒 鉛表面積の依存性を前報 $\left.{ }^{2}\right) の$ 実験結果から検討する。

最初に陽極電流密度 $I_{a}$ について, 陽極で黒鉛単位表 面積当りに流れ，黒鉛酸化に消費される電気量 $C_{a}$ は(2) 式で示されたよらに,サスペンション電位 $E_{\text {sus }}$ の時, 及 び陽極電位 $E_{a}$ の時の最大サスペンション電位 $E_{m a x}$ $\left(E_{\max } \fallingdotseq E_{a}\right)$ 時の $C_{a}$ は，それぞれ(6)式で与えられる。

$$
C_{s u s}=f\left(E_{s u s}, T\right), C_{\max }=f\left(E_{\max }, T\right)
$$

したがって，陽極電流密度 $I_{a}\left(\mathrm{~A} \cdot \mathrm{m}^{-2}\right)$ は，

$$
I_{a}\left(\mathrm{~A} \cdot \mathrm{m}^{-2}\right)=f_{k} \cdot f_{g} \cdot u\left(\mathrm{~m} \cdot \mathrm{s}^{-1}\right) \cdot S_{v}\left(\mathrm{~m}^{-1}\right) \cdot
$$

$$
\left(C_{m a n}-C_{s u s}\right)\left(\text { coulomb } \cdot \mathrm{m}^{-2}\right)
$$

で与えられる。ここに $u, f_{k}$ 扩よび $f_{g}$ はそれぞれ流速 $\left(\mathrm{m} \cdot \mathrm{s}^{-1}\right)$ ，装置上のファクターおよび黒鉛の粒度や表面 性質などに基づくファクターである。したがって，単位 容積中の黒鉛の単位表面積当りにチャージするのに関係 する陽極電流密度 $i_{a}\left(\mathrm{~A} \cdot \mathrm{m}^{-1}\right)$ は(7)式より,

$$
i_{a}\left(\mathrm{~A} \cdot \mathrm{m}^{-1}\right)=I_{a} / S_{v}=f_{k} \cdot f_{g} \cdot u \cdot\left(C_{\max }-C_{s u s}\right) \cdots(8)
$$

となる。本実験では $f_{k}$ 拈よび $u$ は同一条件下でかくは
んも一定であり，また液温は同一であるので，これらは 一定と考えられる。

次に, 単位時間に銅板の単位表面積当りに衝突する黒 鉛粒子の総表面積 $S_{c u}\left(\mathrm{~s}^{-1}\right)$ は,

$$
S_{c u}=f_{k} \cdot f_{g} \cdot u \cdot S_{v}
$$

で与えられる。したがって，銅エッチング速度 $V_{e}(\mathrm{~m} ・$ $\left.\mathrm{s}^{-1}\right)$ は，黒鉛表面積当り銅溶出に消費される電気量を $C_{e}\left(\right.$ coulomb $\left.\cdot \mathrm{m}^{-2}\right)$ とすると,

$$
\begin{gathered}
V_{e}\left(\mathrm{~m} \cdot \mathrm{s}^{-1}\right)=S_{c u}\left(\mathrm{~s}^{-1}\right) \cdot C_{e}\left(\text { coulomb } \cdot \mathrm{m}^{-2}\right) \\
k_{F}(\mathrm{~g} \cdot \text { coulomb } \\
-1) / 10^{6} d\left(\mathrm{~g} \cdot \mathrm{m}^{-3}\right) \ldots \ldots
\end{gathered}
$$

で与えられる。ここに $k_{F}$ および $d$ はそれぞれ銅の電気 化学当量打よび密度 $\left(\mathrm{g} \cdot \mathrm{cm}^{-3}\right)$ である。したがって(9)式 より,

$$
V_{e}=f_{k} \cdot f_{g} \cdot u \cdot S_{v} \cdot C_{e} \cdot k_{F} / 10^{6} d
$$

が得られる。流速 $u$ の効果については, Faul ら の説 明による衝突頻度に相当するが， $V_{e}$ は $C_{e}$ がある特定值 を取ったとすると $S_{v}$ にも依存する。それゆえ衝突頻度 のみではなく, $V_{e}$ は $u \cdot S_{v}$, すなわち衝突黒鉛粒子の総 表面積に依存する。また，エッチング時の銅の電位（後 3-3 で考察するように混成電位) を $E_{c u}$ とすれば，この 電位での黒鉛単位表面積当りの電気量は前述のようにし て決定でき，これを $C_{c u}\left(\mathrm{coulomb} \cdot \mathrm{m}^{-2}\right)$ とすると， $C_{e}$ は

$$
C_{e}=C_{s u s}-C_{c u}
$$

となる。

\section{(a) 懸濁量の効果}

$30^{\circ} \mathrm{C} ， 0.5 \mathrm{M}$ 硫酸溶液中で $200 \sim 250$ メッシュの黒鉛 を $80 \mathrm{~g} \cdot l^{-1}$ から $265 \mathrm{~g} \cdot l^{-1}$ と眯濁量を変化させ， $1 \mathrm{~V}$ の 定電位でサスペンション電解した時の銅エッチング速度 $V_{e}$ と安定なアノード電流 $I_{s}$ を単位容積中の黒鉛の単位 表面積 $S_{v}$ で割った值と懸濁量との関係を図 4 に示す。 この図には残余電流 $I_{r}$ を $S_{v}$ で割った值と懸濁量との関 係も示す。これらはいずれも眯濁量の増加により増大し た。これらは単位容積中の黒鉛粒子の単位表面積当りの 值であり，黒鉛は同一粒径であるので黒鉛の表面粗さな ぞの表面性質による表面積の増加とは考え難く, むしろ 懸濁量の増加により単位容積当りの充てん率が増加し, 陽極あるいは銅板へ衝突する黒鉛粒子が相互につながっ て実質上の面積の増加が起るためと考えられる。すなわ ら本実験の銅エッチング時のサスペンション電位（0.58 〜 $0.46 \mathrm{~V})$ の範囲では, 黒鉛懸濁量の増加は黒鉛のファ クター $f_{g}$ の増大となり, 見掛け上黒鉛の単位表面積当 りの銅エッチング能力の増大となる。

(b) 黒鉛粒度の効果

$30^{\circ} \mathrm{C} ， 0.5 \mathrm{M}$ 硫酸溶液中で黒鉛の粒度を 150 メッシュ 以上，150〜200メッシュ，200〜250メッシュ㧊よび 250 〜325メッシュに分級した $80 \mathrm{~g} \cdot l^{-1}$ を $1 \mathrm{~V}$ で定電位電解 した時, 銅エッチング速度 $V_{e}$, 残余電流 $I_{r}$ 牞よび安定 
なアノード電流 $I_{s}$ はいずれも粒径が小さくなる程増大 した。そこで，黑鉛のファクター $f_{g}$ への粒度の影響を 調ベるために銅エッチング速度 $V_{e}$, 残余電流 $I_{r}$ および 安定なアノード電流 $I_{s}$ を単位容積中の黒鉛の単位表面 積 $S_{v}$ で割った值と黒鉛の平均粒度との関係を図 5 に示 す。いずれも粒径が小さくなる程減少した。これは黒鉛 粒子を今, 球と仮定した時の見掛けの表面積から算出し た值であるが，黒鉛粒子の表面は粗く，その表面積は粒 度により異なり，実際の表面積はさらに大さいだろら。 また，この時の黒鉛の単位体積当りの充てん率は懸濁量 が同一であるので同じである。したがって，本実験の銅 エッチング時のサスペンション電位（0.57〜0. 53Vの範 囲では，図 5 に示される減少は黒鉛の表面性質による表 面積の粒度による増加率が粒径が小さい程, 球形に近く なり減少することに起因すると考えられる。よって黒鉛 粒子の粒径が小さくなると, 黒鉛のファクター $f_{g}$ の減 少となり, 黒鉛の見掛け単位表面積当りの銅エッチング 能力は減少する。ただし，150メッシュ以上の粒径の場 合は, 図 2 で示されたように粒径が大さくて陽極に衝突 した時に酸化されにくいため例外的となったと考兄られ る。

\section{（c）懸濁黒鉛の表面積の影響}

溶液 $1 l$ 中の懸濁黒鉛の総表面積と銅エッチング速度 との関係を図 6 に示す。黒鉛表面積と銅エッチング速度 は注ぼ直線関係で与えられ，黒鉛の眯濁量や粒度などに

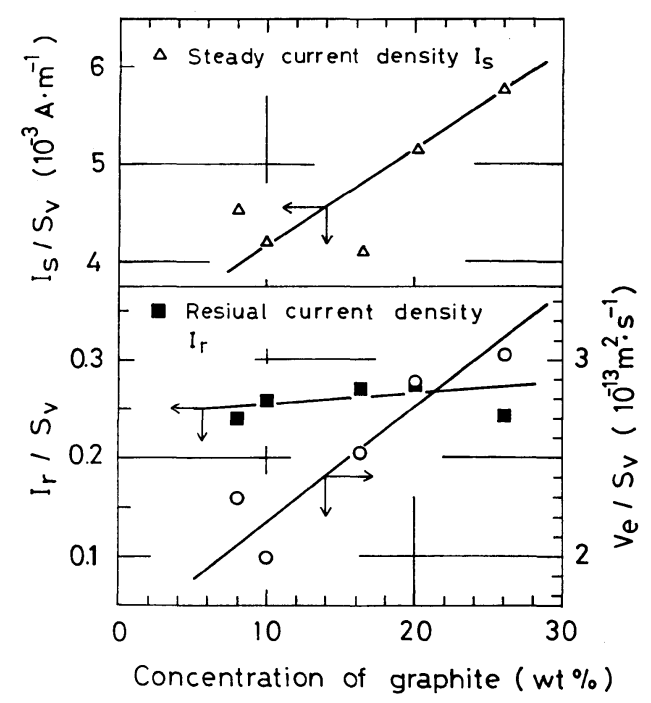

Fig. 4 Relations between the concentration of graphite and $I_{s} / S_{v}, I_{r} / S_{v}$ and $V_{e} / S_{v} . \quad I_{s}, I_{r}$ and $V_{e}$ are the steady current density, the residual current density and the etching velocity of copper, respectively. $S_{v}$ is the total surface area of graphite particles in unit volume of the suspension.
基づく黒鉛のファクター $f_{g}$ に比べ, 銅エッチング速度 への表面積の影響は本実験の銅エッチング時のサスペン ション電位 $(0.58 \sim 0.46 \mathrm{~V})$ 範囲では, 非常に大きいこ とが明らかとなった。また, 本実験に拈ける流速は約 0.1 $\mathrm{m} \cdot \mathrm{s}^{1}$ であり，実用的なェッチング速度 $1.7 \times 10^{-7} \mathrm{~m}$ ・ $\mathrm{s}^{-1}$ (約 $\left.10 \mu \mathrm{m} \cdot \mathrm{min}^{-1}\right)$ を得るためには，黒鉛懸濁量を増 加し, 流速を増大されなければならない。例えば, 粒径 $5 \times 10^{-5} \mathrm{~m}$ の黒鉛を $30 \mathrm{wt} \%$ (約 $19 \mathrm{~m}^{2} \cdot l^{-1}$ ) を用いると図 6 から 概算すると 銅エッチング速度は約 $5.8 \times 10^{-9} \mathrm{~m}$.

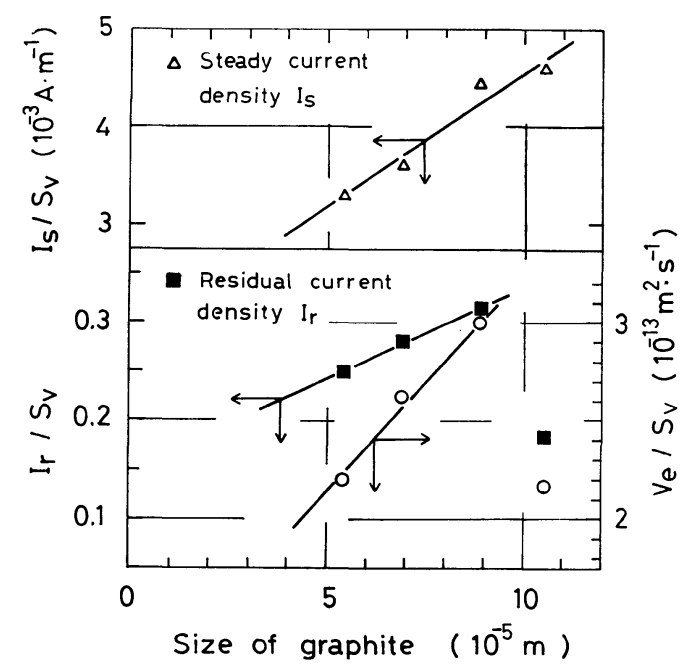

Fig. 5 Relations between the size of graphite particles and $I_{s} / S_{v}, I_{r} / S_{v}$ and $V_{e} / S_{v} . I_{s}, I_{r}$ and $V_{e}$ are the steady current density, the residual current density and the etching velocity of copper, respectively. $S_{v}$ is the total surface area of graphite particles in unit volume of the suspension.

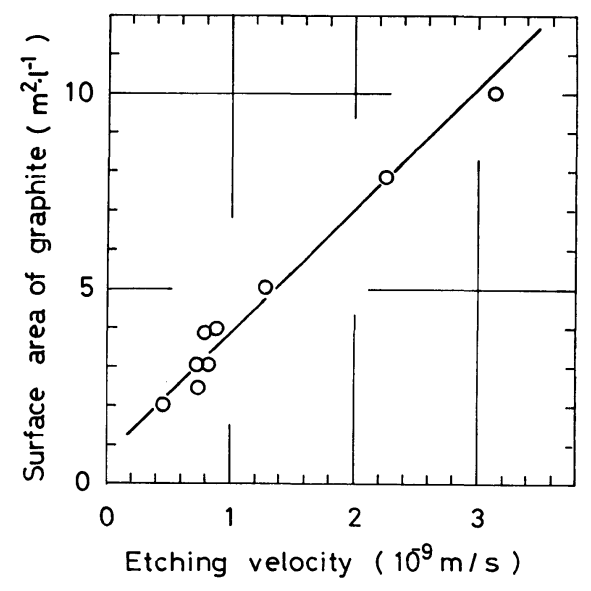

Fig. 6 Relation between the etching velocity of copper and the total surface area of graphite particles in unit volume of the suspension. 


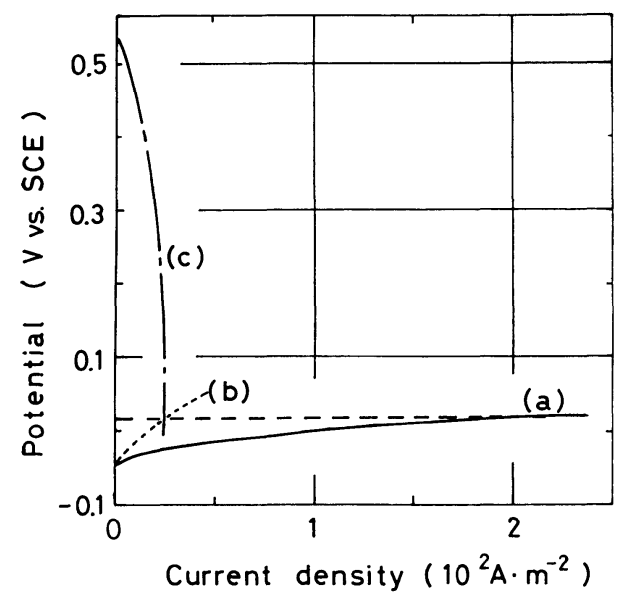

Fig. 7 Expected local cell polarization curve for copper etching. Curves (b) and (c) correspond to the anodic (dissolution) reaction of copper and the cathodic reduction of anodically oxidized graphite species. Curve (a) indicates the anodic polarization curve of copper mea sured in $0.5 \mathrm{M} \mathrm{H}_{2} \mathrm{SO}_{4}$ solution at $30^{\circ} \mathrm{C}$ with a potential sweep rate of $5 \times 10^{-4} \mathrm{~V} / \mathrm{s}$.

$\mathrm{s}^{-1}$ となることから，流速を約 $3 \mathrm{~m} \cdot \mathrm{s}^{-1}$ にすると単純計 算で実用的なエッチング速度が得られる。しかしエッチ ング時のサスペンション電位が実験開始時の電位より常 にかなり卑になった こ2)こから推測されるように，本実 験装置では陽極での黒鉛の酸化が十分行なわれにくく， アノード面積や配置などの装置上のファクターが大きく 影響していると考えられ，これらを改良すれば流速もか なり下げることがでさるだろう。

\section{3-3 銅エッチングの局部電池反応}

250〜325メッシュの黒鉛 $80 \mathrm{~g} \cdot l^{-1}$ を電解した時の銅エ ッチング時のサスペンション電位は $0.53 \mathrm{~V}$, 銅板の電位 は0.02Vであった。また，0.5M 硫酸溶液の $\mathrm{Pt}$ 電極の

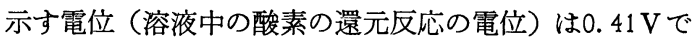

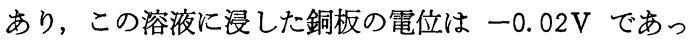
た。さらに窒素ガスを通して脱気した溶液の電位は0.19 $\mathrm{V}$ となり，銅板の電位は $-0.04 \mathrm{~V}$ と卑になった。 $0.5 \mathrm{M}$ 硫酸溶液中に怙ける銅のアノード分極線の測定結果を図 7 の曲線(a)に示す。エッチング時の銅板の電位は $0.02 \mathrm{~V}$ であり, 図7の銅のアノード分極曲線からこの電位での 電流密度 $200 \mathrm{~A} ・ \mathrm{~m}^{-2}$ によるエッチング速度は $7.37 \times 10^{-9}$ $\mathrm{m} \cdot \mathrm{s}^{-1}$ となる。しかし実測値は $8.77 \times 10^{-10} \mathrm{~m} \cdot \mathrm{s}^{-1}$ (電 流密度, $23.8 \mathrm{~A} \cdot \mathrm{m}^{-2}$ ) と小さい。これは銅溶出反応は黒 鉛が衝突することにより進行するので, 実際の溶解時の アノード反応面積は少なくなり，見掛けの電流密度が減 少するためである。したがって，エッチング時の銅のア
ノード分極曲線は図 5 の(b)曲線となり，また上述の測定 結果から予想されるアノードで電解酸化された黒鉛 一酸 素種の 還元反応の 分極曲線は曲線(c)となると考兄られ る。本実験に扣ける銅エッチング時のサスペンション電 位は $0.5 \sim 0.45 \mathrm{~V}$ の範囲内であり黒鉛一酸素種系の還元 反応は, 前報2)で示した黒鉛のサイクリックな分極挙動 よりハイドロキノン $(\mathrm{C}-\mathrm{OH})$ のよらなグループの反応 ((4)式) が主であると考兄られる。また，銅溶出に対す るアノード電流効率が $100 \%$ を越えたことより溶存酸素 の還元反応もこれに加わっていると思われる。以上のこ とより銅エッチング反応は次のような局部電池反応注よ り進行する。

$$
\begin{aligned}
& \text { アノード反応 : } \mathrm{Cu} \rightarrow \mathrm{Cu}^{2+}+2 \mathrm{e} \cdots \cdots \cdots \cdots \cdots \cdots \cdots \cdots \cdots(13) \\
& \text { カソード反応 : }(\mathrm{C}-\mathrm{OH})+\mathrm{H}^{+}+\mathrm{e} \rightarrow \mathrm{C}+\mathrm{H}_{2} \mathrm{O} \quad \cdots \cdots . .(4) \\
& \text { 扤よび } \left.\mathrm{O}_{2}+4 \mathrm{H}^{+}+4 \mathrm{e} \rightarrow 2 \mathrm{H}_{2} \mathrm{O}\right) \cdots(3)
\end{aligned}
$$

\section{4. 結 論}

黑鉛サスペンション法による銅エッチングにおよぼす 黒鉛の表面積および黒鉛の粒度や懸濁量の影響を調べ, 銅エッチング機構について検討した。

（1）黒鉛のサスペンション電位はアノードで電解酸化さ れた黒鉛ー酸素種系のレドックス電位を示す。このサス ペンション電位は主にアノード酸化により䯚濁黑鉛粒子 の単位表面積当りに蓄積した電気量によって決まる。

(2) 銅エッチング速度は本実験のサスペンション電位範 囲内では単位時間当り銅板に衝突する黒鉛粒子の総表面 積により主に決まり，この総表面積が大きいほど銅エッ チング速度は速い。

（3）黑鉛の見掛け単位表面積当りの銅エッチング能力は 黒鉛懸濁量が多い程大きくなる。しかし黒鉛粒径が小さ くなる程減少する。

（4）銅エッチングは次のような局部電池反応で進む。 アノード反応: $\mathrm{Cu} \rightarrow \mathrm{Cu}^{2+}+2 \mathrm{e}$ カソード反応 : $(\mathrm{C}-\mathrm{OH})+\mathrm{H}^{+}+\mathrm{e} \rightarrow \mathrm{C}+\mathrm{H}_{2} \mathrm{O}$ および一部 $\mathrm{O}_{2}+4 \mathrm{H}^{+}+4 \mathrm{e} \rightarrow 2 \mathrm{H}_{2} \mathrm{O}$

(1979-3-5 受理)

\section{文献}

1) W. Faul, B. Kastening und J. Divisek : Ein neues Verfahren zur Kuperätzung bei der Leiterplatten herstellung, Galvanotechnik, 65, 736 (1974)

2 ）沖猛雄，国枝義彦; 黒鉛サスペンション法による銅 のエッチングについて，30,525 (1979)

3) K.F. Blurton: An Electrochemical Investigation of Graphite Surfaces, Electrochimica Acta, 18, 869 (1973) 